\title{
Rigidity Measures. On Constitutional Amendment
}

\author{
Dag Anckar \\ Åbo Akademi University \\ Department of Political Science \\ Fänriksgatan Åbo, Finland
}

\begin{abstract}
Findings in the literature on the explanatory power of constitutional rigidity tend to be inconsistent and at times even contradictory. One possible explanation for this state of affairs is that methods for operationalizing and measuring rigidity levels are still somewhat intuitive and un-precise. Classifying and categorizing constitutional amendment procedures and strictly applying a view of rigidity as a constitutional variable, an attempt is made here to design a rigidity grading that runs from a zero point on a scale that makes use of half-point as well as full-point intervals. Observations on methods for assessing patterns of legislative and popular sovereignty as well as combinations of these sovereignty types are followed by observations on varieties of double decision rules. Illustrations of the multitude of amendment politics are inserted frequently in the presentation, as are extracts from relevant sections of constitutional law in different countries.
\end{abstract}

Keywords: Constitutional amendment, constitutions, double decisions, majority prescriptions, rigidity.

\section{INTRODUCTION}

Almost all countries of the world have written constitutions. Some of these constitutions are more rigid than others, rigidity denoting the difficulty of the constitutional amendment process. Over the years, an abundance of research efforts have been devoted to the task of measuring rigidity and relating rigidity differences to other features of political and constitutional life, like modernity, constitutional endurance, and amendment rates [e.g. 5; 6, pp. 22-23; 31, pp. 218-223; 31; 35]. However, the findings have not been linear and clear-cut. Indeed, the title of an important contribution to this field of research is 'Does the constitutional amendment rule matter at all?' [23], and reviewing the capacity of differing rigidity conceptions for explaining constitutional amendment variation, the author of another leading contribution poses the question if the pro-intuitive obstructing effect of institutional rigidity has in fact been over-estimated [33, p. 355]. According to the same author, it is a challenge to the further debate on constitutional politics to solve this puzzle $(33$, p. 355). While this present undertaking is within the research field in question, it does certainly not aim at solving the rigidity puzzle once and for all. The ambition is more modest and stepwise, as the study aims at outlining and evaluating a scheme of analysis to approach the rigidity notion.

Still, the task is anything but easy. While acknowledging that determining which constitutions are flexible and which are not is an important question, Tom Ginsburg and James Melton recognize that 'measuring flexibility presents tricky methodological issues', not least because there is 'tremendous variation in the amendment procedures used from one country to the next' $[23$, pp. 1-2, 5]. As evident from some random examples, classification problems abound. Constitutional amendment in a given unicameral country A requires a two-thirds parliamentary majority; in another and now bicameral country B the requirement is for 
majority decisions in both chambers. Which method is more rigid, does a qualified majority in one instance outflank or not ordinary majority decisions in two instances? Furthermore, if the answer to this question is in favor of the second alternative, what if the majority threshold that is prescribed in the first alternative is raised to three-fourths instead of two-thirds? And how is the method to be evaluated and classified which is applied in Brazil and requires that amendment proposals are accepted twice in the one House and twice also in the second House, and further demands that all these decisions are taken by three-fifths majorities? [Constitution article 60; 37, p. 131]. Or, to add still one example, now taken from the constitutional practice of federal Ethiopia, how is one to classify a method that requires, first, a two-thirds majority in a joint sitting of the two Parliament Houses, and, second, approval also in two-thirds of the state legislatures in that country? [article 93; 1, p. 303].

A particular complication is when constitutions stipulate different methods of amendment for different provisions in the constitution; when this happens, classification obviously requires that choices are made on the basis of the one or the other criterion [e.g. 5; 31, pp. 218-221]. The problem reappears in methods that prescribe alternative proceedings, like in Cameroon, where amendment requires a parliamentary majority decision; however, the President may request a second reading, in which case the amendment is accepted by a two-thirds parliamentary majority. Furthermore, the President may decide to submit any bill to amend the constitution to referendum [article 63; 41, p. 161]. It happens that the alternate proceedings are dependent on each other, like in Burkina Faso, prescribing referendum approval but allowing the referendum stage to be dropped when the amendment proposal is accepted in Parliament by a three-fourths majority [article 164]. It may also be the case, this is a similar problem, that the procedure is dependent on the method for initiating amendment. In the Republic of the Congo the requirement is for a referendum if the initiative emanates from the President; if it emanates from Parliament, the requirement is for a two-thirds majority of the members of the two parliamentary chambers in joint sitting and for a following referendum [article 186; 36, p. 221].

It is the aim of this article to bring some order to the chaos that has been described above. Specifically, the aim is to present a classification scheme of constitutional rigidity that is lucid and conclusive as well as sufficiently detailed. The course of presentation resembles much a line of thought by Lijphart, who notes that 'constitutional amendment may take many different forms' and further notes that 'this variety can be reduced to three basic types' [30, p. 89]. The transfer from 'different forms' to 'basic types' advances here in five steps. The first step is taken in the form of the introductory remarks above; the second follows in the next section that contains a series of specific considerations on methodology and method. There follow two consecutive steps, the first of which involves the construction of a preliminary scheme of analysis, designed to capture main features of rigidity profiles, and the second of which moderates the scheme by inserting observations on so-called double decision rules. Finally, a fifth step contributes some concluding remarks and an illustrative empirical presentation.

\section{Points of Departure}

Before the analysis proceeds, a few basic choices need to be explained at some length. In all, five considerations apply:

(1) Rigidity is in this research conceptualized as a constitutional variable. This means that rigidity is a constitutional feature that may serve as an independent variable in efforts to explain variations in other constitutional variables like, say, amendment rates, or in nonconstitutional variables like, say, political system legitimacy conceptions. Also, rigidity may serve as a dependent variable in efforts to grasp the impact on rigidity of non-constitutional or 
constitutional variables, like political party constellations or the federal or non-federal status of the state. From the rigidity concept, therefore are below peeled all circumstances and conditions that abide in the terrain that concerns the coming about of rigidity or the constitutional or societal consequences of rigidity. Of course, many of these circumstances remain by virtue of essentiality and scope in the center of rigidity research. For example, a defense as well as a criticism of rigidity may depart from normative consideration and it is one vital task in research to penetrate and elucidate the actual frames of reference. One may ask if it is really justified to extend rigidity protection to enactments that concern freedoms and liberties - such a protection tends to cement the freedom and rights conceptions of a given generation, and thereby renders difficult any consideration of the perhaps different valuations of later generations. On the other hand, however, one may well ask if future qualified majorities should really be authorized to intervene against freedoms and rights that have been once issued and are since regarded by many as ageless in nature [e.g. 18]. Still, as noted, such important issues and the debates they have inspired or may inspire are outside the frame of this essay.

However, in regards to rigidity causes in particular, one may yet advocate the view that environmental aspects need preferably be observed and considered in attempts at conceptualize and measure constitutional rigidity. Namely, it may be the case that a certain level of rigidity, like a two-thirds parliamentary majority, is easier to achieve in a given country A than in another given country B. This would be, for instance, in consequence of A maintaining a plurality electoral method which reduces the number of parties and thereby smoothens a march towards a two-thirds threshold [17, pp. 19-48; 31, pp. 218-223; 34, pp. 20-24]. In other words, while numerical rigidity assessments of two systems may result in the same scores, the systems may still for environmental and political reasons differ in terms of amendment difficulty, and this difference should reflect in the actual rigidity grades of the systems. Admittedly, this objection has some empirical backings. Research on amendment procedures indicates that the step from amendment prescriptions for a two-thirds majority to prescriptions for a three-fourths majority is often the outcome from rational calculation - a higher degree of rigidity is in demand quite simply because circumstances that relate to electoral system characteristics or to a high degree of societal fragmentation promote in given countries a need for pronounced threshold levels [3]. What is needed in rigidity classifications, this is the essence of the objection at hand, is an understanding that numerically similar rigidities are not necessarily equally severe. Differing circumstances and factors transmit differing meanings to similar numerals; these circumstances and factors therefore, in one way or another, become part of the rigidity measures.

Against such views, objections may however be raised. Lorenz also regards rigidity as a constitutional variable, and she makes an important point in writing that any consideration of the real allocation of political power in an index of constitutional rigidity 'would endanger the elegant simplicity of the concept and the validity of case classifications concerning longer time periods' [33, pp. 343-344]. To this may be added a kindred perspective. Attempts to introduce externalities into definitions tend to reduce unduly the scope of research and to define away important research questions. Admittedly, such mistakes are frequent in political studies. They appear, for instance, in definitions of democracy that are often opened up to include factors that promote democracy or are promoted by democracy. Such approaches are, however, in conflict with a sound methodological precept which states that definitions of a concept should not include aspects that are about determinants, conditions and consequences of that same concept - when and if this rule is violated, the researcher deprives himself or herself of studying these aspects empirically [e.g. 24, p. 32; 32, pp. 19-24]. The implication of this is that 
contemplating rigidity as a constitutional variable represents foresight and reason: measuring rigidity is one thing, researching rigidity sources or rigidity consequences are another thing. Of course, to repeat, researching causes and consequences are important and essential tasks in themselves. They are, however, located in extensions of the process that brings out an understanding of the very meaning and operationalization of rigidity.

(2) The vast literature on constitutions and constitutional change makes recurrent use of the familiar distinction between flexible and rigid constitutions. While a flexible constitution is amended in the manner in which ordinary laws are passed, a special procedure or organ is needed for the amendment of a rigid constitution [e.g. 12, pp. 15-16; 26, p. 211; 30, pp. 213$214 ; 31$, pp. $218-222 ; 39$, pp. 65-66]. One of the many questions that link to this distinction concerns the precise dividing line between the two categories - how much rigidity can be absorbed into the flexible category, how much flexibility can be absorbed into the rigidity category? While absolute answers are perhaps difficult, the effort of this study to measure rigidity accepts that the border is to some extent blurred. The attempt therefore has one further and definite point of departure. This point is that rigidity is not an either-or occurrence, something that exists or does not exist. Rather, rigidity is here looked upon as a more-or-less occurrence, something that exists in varying degrees. Importantly, this approach makes it possible to discriminate between classes and modulations of rigidity, and this, of course, has in its wake consequences in regards to the type of questions that may be posed and answered in research. Not only is the search for explanations why some constitutions are rigid whereas others are not, but also for explanations why some rigid constitutions are more or less rigid than other rigid constitutions.

From this, consequences follow. Besides building on central dimensions, such as prescribed majority levels, the number of decision arenas, and the involved actors, any index construct of rigidity should preferably advance in a stepwise fashion, each step indicating a rigidity increase. The ambition is to design an apparatus that prescribes steps that are about equally high, each step representing roughly the same rigidity addition. However, this line of reasoning is not always possible, and it is inevitable that the efforts at classification that follow here must allow certain degrees of freedom and even arbitrariness. The problem at hand is that separate components that are not always comparable contribute to the differences that prevail between steps. Evidently, higher legislative thresholds and processes involving more actors increase the number of disparate interests that must approve constitutional amendments and therefore add to rigidity; however, the components contribute to rigidity in a somewhat differing manner and their implications can therefore not be added straight off. Also, matters are complicated by the components occurring in varying combinations, some of which counteract and some of which reinforce each other. Be this as it may, the leading strategy in the exercise that follows is to derive a scoring rule according to which severe regulations in terms of difficulty receive more points than less severe regulations. From the fact that 'difficulty' is a concept that is hard to capture, involving much difficulty, a good deal of difficulty, and perhaps only a small degree of difficulty, it follows that the apparatus in sight must register small as well as larger movements over a scale; also, of course, the apparatus must register a lack altogether of difficulty. In short, the aim is to produce a simple but still not oversimplified scale which is neither wide nor tight, this meaning that the scale should not offer alternatives to an extent that invites arbitrariness and should, on the other hand, offer enough alternatives not to become empty and insignificant. The solution here to this puzzle takes the form of a grading that runs from a zero point on a scale that makes use of half-point as well as full-point intervals (0-0.5-1-1.5-2 points, etc.). 
(3) Two particular classification problems have already been hinted at here and they keep turning up in the analyses that follow. The one problem arises when the rules that determine constitutional amendment in a given country in fact, given certain conditions, may alternate. This means, in most cases, that the rules differ in terms of difficulty and therefore receive differing rigidity scores. This is of course no drawback in terms of classification when and if the methods are regarded as methods among others. They are then simply classified in terms of their characteristics. However, comparative rigidity research usually departs from the assumption that a given constitution or a given country is the unit of analysis and is assigned a rigidity score to be compared to the scores of other constitutions or countries. When this is the case, a choice must be made between differing alternatives: which method should be chosen to represent the actual country? Examples that illustrate this problem have been introduced above; the set of rules applied in Benin may be quoted as a further example. In Benin the basic requirement for amendment implementation is a three-fourths parliamentary majority and a confirming referendum; however, Benin also applies an alternative method, according to which the referendum phase can be avoided if four-fifths of the members of the National Assembly approve the amendment [2, p. 103; 33, p. 346]. Now, if the case of Benin is included in a comparative study of rigidity, it is obvious that a classification of this country implies a choice between the two methods that are mentioned here, a choice that must be guided by a reasoned criterion. The choice that is implemented throughout in this study favors the most difficult alternative - when alternative decision methods are suggested, they are ranked separately, and the most difficult method is the one that counts. In the case of Benin, evidently, the main rule $(3 / 4+$ referendum $)$ is more demanding than its exception $(4 / 5)$; in consequence, the main rule survives.

The other problem, similar in nature, emerges when amendments of certain thematically defined issues require more or less rigidity than the amendment of certain other thematic issues. For instance, the constitution of Papua New Guinea identifies and applies no less than three different majority thresholds, and it is explicitly said in the constitution that 'Nothing prevents different majorities being prescribed in respect of different aspects or subject matters of a provision' [article 17; 28, p. 712]. Here, the classification of such cases is again guided by the principle that the most rigorous requirements count, except when evident that the requirement is valid for some very specific article or purpose only [5, p. 212]. Again, to exemplify: the constitution of St Vincent and the Grenadines requires that amendment proposals are submitted to referendum when and if they concern fundamental rights and liberties, the position of parliament, parliamentary elections, the appointment of senators, matters of state finances and public administration, etc. [article 38]. It is evident from this enumeration that the referendum device, although in use for a defined set of matters only, is common enough to direct classification and should count in the rigidity classification. In contrast, in Mauritius the referendum device comes to use in very exceptional cases only, such as the postponement of elections [13, p. 593], and the device may therefore be neglected in rigidity classifications.

(4) Rigidity measures cannot be about final decisions only, but should apply, in like manner, to 'pre-final votes', to use a term introduced by Lorenz [33, p. 347]. Such votes are not about constitutional changes per se, but are rather about the proposal stage, the importance of which for understanding rigidity certainly needs to be acknowledged. This proposal stage may establish methods for determining on beforehand the need for a constitutional reform; these methods, again, may activate majority or other prescriptions that should be observed when calculating rigidity scores. In Argentina, for instance, amendments require a declaration of Congress by a two-thirds majority of the need for a reform, which is then prepared by an 
elected constituent convention meeting especially for that purpose [article 30; 19, pp. 40-41]. Lorenz suggests that rigidity classifications include such pre-final votes by half of the point score that would otherwise come to use - in the case of Argentina, then, while the qualified majority requirement in regards to the initiating actor authorizes a score of rigidity points, the pre-final nature of the actual decision halves this score. This is because 'majorities for draft documents are easier to achieve' [33, p. 347]. The argument appears convincing and is certainly sanctioned here.

(5) The analysis that follows makes frequent use of excerpts from and references to concrete law paragraphs, i.e. passages in constitutions that deal with methods for constitutional amendment and change. The relevant materials that has been consulted in the preparation of this study consists of the constitutions that were in force in the year 2010 in the countries of the world and has been collected from two parallel and principal sources. First, the Constitutions of the Countries of the World, which is a series of updated constitutional texts by Oceana Publications [8, various years], is an excellent guide to the constitutions and constitution-like texts from all parts of the globe. Not only contain the editions complete constitutional texts; in several cases the editors also provide expert commentaries as well as historical notes and reviews and annotated bibliographies. The second source, likewise useful, is the 3-volume set Encyclopedia of World Constitutions, edited by Gerhard Robbers and published in 2007 by Facts on File, New York. The entries of 194 cases, written by country specialists, follow a common structure that makes the systems easily comparable, and the coverage for each country deals explicitly with amendments to the respective constitution and with the valid procedures for the attainment of constitutional change. Furthermore, the websource Constitution Finder, a database of national and state constitutions and related documents, provided by the University of Richmond School of Law, has been used as a supplementary source; the materials from this source, however, are not always satisfying. Some documents are available in un-accessible languages only and at times summaries and abstracts rather than full documentation are available.

\section{On legislative and popular sovereignty}

The frequently used distinction between a legislative and a popular sovereignty forms a natural entrance gate to the analysis at hand. Admittedly, various conceptual and other difficulties are common in discourses on types and sources of sovereignty [e.g. 40, pp. 15-24]. However, in the present context the above distinction aims at no more than the drawing of a boundary line between a political sovereignty that is embedded in the people, and a legislative sovereignty, that is embedded in an organ or institution that may or may not be a representative of the people and takes the form of a parliament, some other lawmaking instance or some individual ruler. In some countries the legislative sovereignty of parliament or some other instance is not challenged by the people, in other countries, however, legislative sovereignty is by provisions on referendum submitted to a control by the political sovereignty. The main dividing line in regards to popular sovereignty is, therefore, if the actual constitutional order issues prescriptions for a constitutional referendum.

While this separation of legislative and political sovereignty forms one dimension that structures the rigidity device that stands out in this section, a second dimension is about the majority prescriptions that prevail in the respective cases. The device combines four classifications on the legislative sovereignty dimension with three classifications on the popular sovereignty dimension; in all, therefore, twelve combinations appear and call for rigidity estimation. The dimensions, the classifications, the combinations, and the allocation of rigidity scores are evident from Table 1, which denotes for each combination the resulting rigidity values which origin from a simple addition, in which to the estimates that are about 
legislative sovereignty are added the estimates that are about popular sovereignty. The Table also includes selected examples of countries that represent the different rigidity categories. For every category, however, empirical examples are not available. The remainder of this section is a prolonged commentary to this Table.

Table 1. Rigidity scores resulting from combinations of legislative and popular sovereignty. With examples.

\begin{tabular}{|c|c|c|c|}
\hline \multirow{3}{*}{$\begin{array}{l}\text { Legislative } \\
\text { sovereignty: }\end{array}$} & \multirow{2}{*}{\multicolumn{3}{|c|}{ Popular sovereignty: }} \\
\hline & & & \\
\hline & Not involved & By majority rule & $\begin{array}{l}\text { By qualified } \\
\text { majority rule }\end{array}$ \\
\hline Not involved & $\begin{array}{l}0+0=0 \\
\text { Vatican City }\end{array}$ & $\begin{array}{l}0+2=2 \\
\text { Ghana }\end{array}$ & $\begin{array}{l}0+3=3 \\
\text { Micronesia }\end{array}$ \\
\hline By majority rule & $\begin{array}{l}0+0=0 \\
\text { Indonesia }\end{array}$ & $\begin{array}{l}0+2=2 \\
\text { Lesotho }\end{array}$ & $0+3=3$ \\
\hline $\begin{array}{l}\text { By qualified } \\
\text { majority rule }\end{array}$ & $\begin{array}{l}2+0=2 \\
\text { Hungary }\end{array}$ & $\begin{array}{l}2+2=4 \\
\text { Guatemala }\end{array}$ & $\begin{array}{l}2+3=5 \\
\text { Marshall Islands }\end{array}$ \\
\hline $\begin{array}{l}\text { By super-majority } \\
\text { rule }\end{array}$ & $\begin{array}{l}3+0=3 \\
\text { Mauritius }\end{array}$ & $\begin{array}{l}3+2=5 \\
\text { Niger }\end{array}$ & $3+3=6$ \\
\hline
\end{tabular}

In the Table, 'legislative sovereignty' refers operationally to a possible participation of parliament in the management of constitutional change, and in regards to this participation, as evident from the Table, four notations may be applied. The first implies, quite simply, nonparticipation, this meaning that parliament is not involved in the final stages of decisionmaking, which are, instead, a concern of other instances. These may be individual rulers like in Oman, where the Basic Statute Law shall not be amended except in the manner it was promulgated [article 81, Sultanate Decree]. Other examples are Saudi Arabia, where the provisions of the Basic Law are amended by Royal Decree [article 25], or the Vatican where the Supreme Pontiff 'has the fullness of legislative, executive and judicial powers' [article 1; 15, pp. 415-417]. Also, the involvement of other instances may refer to arrangements, quite rare in practice, where the people alone manages the right of decision, like in federal Palau, where proposed amendments become effective only when approved in referendum by a majority of the votes cast on that amendment and in not less than three-fourths of the states [article XIV]. A similar formula is in use in the Federated States of Micronesia, where proposed amendments must be approved by three-fourths of the votes cast on the amendment in each of three-fourths of the states [article XIV; 27, p. 606]. Of course, as they bypass parliamentary authority, these methods do not authorize a giving out of rigidity points as far as legislative sovereignty is concerned. The remaining three notations about legislative sovereignty concern situations in which parliament indeed assumes a role as decision-maker; these notations have reference to the actual majority thresholds that are used.

The first notation is about situations in which parliament decides on amendments by a simple majority rule which does not, accordingly, deviate much or not at all from methods of ordinary lawmaking. England, Iceland, New Zealand and Sweden are examples of countries that apply, although with variations, this method. As it does not yet imply a noteworthy increase in amendment difficulty, the method does not qualify for rigidity points. The second notation is about situations where parliament decides by qualified majority, this term denoting prescriptions for a two-thirds majority or a similar-sized majority like three-fifths, the first alternative being used in, for instance, Angola [article 169] and Belgium [article 195], and the 
second being applied, for instance, in Nicaragua [article 194]. Evidently, these methods stand for a considerable increase in difficulty and it seems an adequate and proportionate solution to credit the use of the methods with a score of two (2) rigidity points. The next and final notation concerns situations in which parliament decides with a majority that exceeds the two-thirds threshold and then usually is of the size of three-fourths or even more - in Niger, for instance, a four-fifths majority is required [article 174]. Such majorities are supermajorities and they are of course more demanding still in terms of rigidity. However, the difference between a qualified majority and a supermajority is less dramatic than the difference between an ordinary and a qualified lawmaking, and therefore justifies the allocation of only one (1) additional rigidity point.

As regards constitutional referendums, five separate notations follow. The first concerns countries that do not apply the referendum institution in amendment processes - of course, when this is the case, rigidity points on account of popular sovereignty may not be granted. This notation, this may be said in passing, is valid for approximately half of the countries of the world [4]. The second notation is about countries that apply simple majority referendums: amendment proposals pass when approved by a majority of the electors. A prescription to that effect gives out two (2) rigidity points. In practice, the implementation of such prescriptions may vary considerably - it may happen, as already mentioned, that special circumstances render referendums mandatory rather than compulsory, and it happens that special circumstances render the referendum superfluous. In addition to earlier references, two more examples may be given. In Gambia referendums must be arranged when and if the President refuses to sanction an amendment proposal that has met with parliamentary approval [article 226]. In the Democratic Republic of the Congo the requirement is for a constitutional referendum that may, however, be avoided if the two Houses of Parliament in joint sitting pass the amendment proposal in question with a three-fifths majority [article 218]. Finally, this is the third notation, the requirement may be that the referendum vote produces a majority which is qualified, i.e. larger, in some sense, than an ordinary majority.

Such a requirement is not common, but is not very rare, either. For instance, in Antigua and Barbuda the amendment requirement is for a two-thirds majority of the votes in the referendum that follows parliamentary deliberation [article 47]. The same principle is valid in Namibia [article 132; 33, p. 347] and, for instance, in Montenegro which applies, however, a three-fifths majority threshold [article 157]. Furthermore, prescriptions for qualified majorities are common in federal states, where the ambition to involve the state level in amendments that concern autonomy issues comes natural [e.g. 7]. For instance, in Australia amendments require the approval of both Houses of Parliament, followed by a referendum that achieves majority support overall and in a majority of states [article 128; 16, p. 56; 26, p. 211; 39, pp. 15-16]. The qualified procedures mentioned here authorize an addition of one (1) rigidity point to the two (2) points earned by the mere initiation of a referendum procedure.

The fourth notation is about referendums that are part of pre-final votes. In such cases, rare as they are, the specific rules for estimating pre-final votes of course apply, which means that only half scores are registered. In the Seychelles certain fundamental provisions are amended by a two-thirds parliamentary majority only if 60 percent of all voters have agreed in a referendum - the procedure in this small island country, then, is contrary to the usual method of submitting parliamentary decisions to probation in referendum [9, p. 812; 42, p. 777]. Finally, while in some cases it is a valid requirement that a certain portion of the electorate actually turn up at the ballot box and support the proposal in question, other cases do not operate such stipulations. For instance, in Ghana a change of entrenched provisions requires a majority vote in a referendum and at the referendum at least 40 percent of registered voters must vote and 
at least 75 percent of the persons voted must vote in favor of the Bill in question [article 290; 20, p. 350]. In like manner, the Constitution of Armenia declares that a draft put to referendum is deemed adopted 'in case more than half of the participants of the voting but not less than one fourth of citizens enrolled in electoral lists have voted in favor' [article 113]. Clearly, these are more strict prescriptions than the one in use, for instance, in the Bahamas, which simply states that the majority of the electors voting must approve the Bill in question [article 54]. The same applies to Moldova, where provisions regarding certain entrenched matters are revised only by a referendum that is based on a majority vote of the registered voting citizens [article 142]. While the difference between the calculation methods is perhaps less than dramatic in terms of amendment difficulty, the difference is still evident enough to authorize for the first method a grade increase of 0.5 point.

The property space that has now been dissected extends over a large number of variations and alternatives. At a zero point are systems that do not really fit the categories of legislative and popular sovereignty; these systems, as noted, in the main vest the right to make amendment decisions in individual rulers and actors. On the other hand, a maximum score of six (6) rigidity points is attributed to systems that apply prescription for a super-majoritarian legislative sovereignty and add prescriptions for a qualified-majoritarian popular sovereignty. However, the task of establishing a complete rigidity classification is still not completed. The result so far is only a skeleton, a basic construct that keeps many concrete systems in order, but certainly not all. Further distinctions need to be deliberated; they are dealt with in the following.

\section{Double decision rules}

Further considerations are instituted here by the introduction of the terms repetition and extension, which denote varieties of double decision rules. Repetition refers to situations where the one and same instance deals with a given amendment issue at repeated occasions, whereas extension implies that more than one instance handle decision-making authority in regards to legislative sovereignty matters. These additional distinctions and appending subdistinctions are presented in Table 2, which also reports estimations of the resulting rigidity point scores. The remainder of this section is in the main a commentary on the Table.

Table 2. Double decision applications: rigidity scores.

\begin{tabular}{|l|l|}
\hline Repetition, swift & 0 point \\
\hline Repetition, detained & 1 point \\
\hline Extension, joint sitting & 0,5 point \\
\hline -if majority rule (M) & add nothing \\
\hline -if qualified majority rule (QM) & add 2 points \\
\hline -if supermajority rule (SM) & add 3 points \\
\hline Extension, parallelism & 0,5 point \\
\hline -if M + M & add nothing \\
\hline -if QM + M & add 2 points \\
\hline -if QM + QM & add 2 points \\
\hline -if SM + M & add 3 points \\
\hline -if SM + QM & add 3 points \\
\hline -if SM + SM & add 3 points \\
\hline Extension, control & \\
\hline -if submission & 1 point \\
\hline -if referral & $\begin{array}{l}\text { various possible outcomes: } \\
\text { the most demanding } \\
\end{array}$ \\
\hline
\end{tabular}


As regards repetition, the guiding principle is simple enough: if an instance deliberates and decides on a constitutional change at two or even more occasions, this counts for more in terms of rigidity than the method of deciding the matter in one sitting. For instance, the Danish method of prescribing majority decisions in two parliaments with intervening elections [article 88; 14, p. 254] is clearly a more demanding procedure than one which requires one parliamentary majority only. One aspect to consider is when the time that elapses between two or more votes is short, as in, for instance, Sierra Leone, where a two-thirds majority is called for 'on the second and third readings' [article 108], and in the Solomon Islands, where a similar two-thirds majority is called for in 'two separate readings' [article 61]. Obviously, these are moderate forms of repetition, meaning that the one and same parliament in the same composition decides on the same issue with a short time interval only between decisions. Such a short delay between readings of bills appears symbolic rather than real in terms of sustained popular engagement and does not authorize additional rigidity points. In contrast, the implication of the Danish case and others, like Finland, Iceland and Sweden, is that two notidentical parliaments under a prolonged period test and retest the amendment in question. Here, obviously, the delay mechanism is real and demanding to an extent that motivates a grade increase of one (1) rigidity point. In separate cases the same measure is justified even in the absence of intervening elections. In Eritrea amendments require, first, a three-fourths parliamentary majority, and, second, a four-fifths majority when at least one year has elapsed since the time of the first vote [article 59; 25, p. 294]. A proper time gap is prescribed; furthermore, the rigorous majority rule has been even more tightened.

Turning from repetition to extension, three main variants of this second strategy are dissected. One variant, called 'joint sitting', is when two instances of legislative sovereignty merge for dealing with an amendment proposal; specific majority requirements may or may not apply to this joint sitting. If they apply, they need to be registered. In Mauritania, for instance, bills to amend the Constitution are presented to the two Houses of Parliament convened jointly as Congress; then, a three-fifths majority in Congress is necessary for the amendment [article 101; 44, pp. 588-589]. The use of the joint sitting formula yields a half rigidity point; in addition, the requirement for a qualified majority threshold necessitates two (2) more rigidity points. In all, therefore, a classification of the rigidity of the Mauritanian constitution results in the count 0.5 $+2=2.5$ points. A second variant is about 'parallelism', this term denoting situations in which two or more instances, e.g. two parliamentary chambers, in separate sittings consider the actual reform proposal. The fact that the parallelism strategy is used motivates in itself a rise of the rigidity score of the magnitude of 0.5 point; in addition, the majority requirement that comes to use again needs to be registered. If the two instances both use the same threshold, asking for, say, two-thirds majorities, this threshold forms the basis of classification; if separate thresholds are used, the one that is more demanding applies. In Trinidad and Tobago, for example, amendment of specially entrenched matters requires the consent of a three-fourths majority in the House of Representatives and a two-thirds majority in the Senate [article 54]; consequently, the first notation, which is more demanding, applies. A classification of the rigidity of the Trinidad and Tobago Constitution therefore results in the formula: 0.5 point on account of the use of parallelism +3 points on account of the use in parallelism of a supermajority threshold $=3.5$ rigidity points.

A third variant is here named 'control'; this variant has two forms. The first is about control as submission - two separate declarations of will are required for a constitutional amendment to come about, but the one will is sub-ordinated to the other. The arrangements in Kuwait provide one example, as they prescribe that constitutional change must be endorsed by a twothirds parliamentary majority; once this has happened, the change thereafter gains legal force 'only after being sanctioned and promulgated by the Amir' [article 174]. In Liechtenstein, to 
mention another example, 'any amendment needs the subsequent assent of the Reigning Prince' [38, p. 542], in Swaziland, to mention still one example, before the bill in question is submitted to the King for assent [10, pp. 81-82], the requirement is for a three-fourths majority of the members of the two Houses in joint sitting [sections 245-247]. Since these practices introduce new veto-players [43], a rigidity increase is implied which should be registered in the form of one (1) additional rigidity point. The second form is about control as referral, the meaning of which is that decisions from one instance are referred to probation in another or several other instances or are rather exempted from such probation. Such is the case in France, where the President can avoid the remittance of a parliamentary decision on constitutional reform to referendum by submitting the issue anew to Parliament, in which case a third-fifths majority of the votes of the members of the two chambers in joint sitting is required for the bill in question to be passed [article 89; 29]. Similar practices from constitutional life in Cameroon and Gambia were mentioned earlier in this study; still further examples are as a rule from presidential and semi-presidential systems that have vested the respective control functions in the holder of executive power. Since the control methods in this category often express differing degrees of difficulty, the guiding rule in this classification scheme of giving precedence to the most demanding alternative applies.

\section{Closing}

Explanatory efforts in the comparative politics compartment are usually about variation, the research task being to explain how variations in one or several variables relate to variations in one or several other variables. Still, variance is not always a self-evident and easy-to-recognize pattern. There are instances where variance is in fact in short supply, and it is very much in the nature of things that constitutional rigidity is among these factors - there are not so many countries in the world, the number of rigidity measures and techniques at their disposal is after all restricted. Little wonder, then, that several countries behave in similar fashion and that there is a small variance only in the country profiles. Indeed, comments in the literature on rigidity perceptions often complain about an incapacity of models to dissect indistinct lumps of observations and categorizations [e.g. 23; 33].

This closing section of the paper at hand briefly addresses this difficulty by means of an admittedly rudimentary mapping, the ambition of which is to find out how the rigidity concept that has been derived actually performs in terms of variance. Total rigidity scores are registered in Table 3 for the independent states of the world, the names of which start with the letter S. Of course, this case selection does not follow from considerations on representation and the like, but is no more than a convenient shortcut to a sample that stands for a certain amount of randomness in terms of culture, regime, and institutional set-up. The situation in the year 2010 is targeted; therefore, the case of South Sudan, independent in 2011, has been left out. The case of Somalia, in lack of a recognized central government, is likewise excluded. 
Table 3. Rigidity scores for a sample of 25 countries.

\begin{tabular}{|lr|lr|}
\hline Saint Kitts and Nevis & 5 & Slovenia & 2,5 \\
\hline Saint Lucia & 3,5 & Solomon Islands & 3,5 \\
\hline Saint Vincent and the Grenadines & 6 & South Africa & 3,5 \\
\hline Samoa & 2,5 & South Korea & 5 \\
\hline San Marino & 2 & Spain & 7 \\
\hline Sao Tomé and Príncipe & 4,5 & Sri Lanka & 4,5 \\
\hline Saudi-Arabia & 0 & Sudan & 3 \\
\hline Senegal & 2 & Suriname & 2,5 \\
\hline Serbia & 4,5 & Swaziland & 6 \\
\hline Seychelles & 3,5 & Sweden & 1 \\
\hline Sierra Leone & 3 & Switzerland & 0 \\
\hline Singapore & 5,5 & Syria & 3,5 \\
\hline Slovakia & 2,5 & Average & 3,5 \\
& & & \\
\hline
\end{tabular}

This exercise, in fact, brings about a promising result as it indicates an ability of the model to identify and register empirical variation. The 25 countries are in Table 3 placed on a rigidity scale with half-point intervals, running from 0 to 7 points, which is the highest value scored by any individual country in the sample. This means, then, that the scale has 15 grades, and no less than 11 of these grades have empirical reference points in the form of one or several countries. Furthermore, the gaps in the references are not concentrated on certain segments of the scale, which would perhaps suggest built-in imbalances and coverage flaws of the scale. Rather, the gaps are spread widely, as they appear at the locations of $0.5,1.5,4$ and 6.5 rigidity points. The satisfactory spreading over the scale is evident also from the fact that 11 countries are registered in the rigidity interval between 0 and 3 points as against 14 countries in the 3.5 to 7 point interval. As evident from the Table, the average rigidity score is 3.5 points.

\section{References}

Aberra, R. M. (2007): Ethiopia. In: Robbers, G. (ed.): Encyclopedia of world constitutions, Volume 1. New York, Facts on File, pp. 300-303.

Adjovi, R. (2007): Benin. In: Robbers, G. (ed.): Encyclopedia of world constitutions, Volume 1. New York, Facts on File, pp. 100-103.

Anckar, D. (2012): Constitutional amendment methods in twenty-one small island democracies. Island Studies Journal 7: 259-270.

Anckar, D. (2014): Constitutional referendums in the countries of the world. Journal of Politics and Law 7: 12-22.

Anckar, D., Karvonen, L. (2015): Constitutional amendment methods in the democracies of the world. In:

Mikulego, P., Kuliga, A., Karpa, J., Kucy, G. (eds.): Ustroje tradycje i porównania. Wydawnictwo Sejmove, Warzawa, pp. 205-218.

Benz, A. (2013): Balancing rigidity and flexibility: Constitutional dynamics in federal systems. West European Politics 36: 726-749.

Benz, A., Colino, C. (2011): Constitutional change in federations - A framework for analysis. Regional \& Federal Studies 21: 381-406.

Blaustein, A. P., Flanz, G. H. (eds., various years): Constitutions of the countries of the world. Dobbs Ferry, NY, Oceana.

Blumenstock, M. (2007): Seychelles. In: Robbers, G. (ed.): Encyclopedia of world constitutions, Volume 3. New York: Facts on File, pp. 810-812.

Booysen, S. (2013): The legislature of Swaziland - compromised hybrid. In: Baldwin, N. D. J. (ed.): Legislatures of small states. London and New York, Routledge, pp. 81-91.

Constitution Finder. Retrieved from: http://confinder.richmond.edu/ 
Derbyshire, J. D., Derbyshire, I. D. (1999): Political systems of the world, Volume One. Oxford, Helicon Publishing. Domah, S. B. (2007): Mauritius. In: Robbers, G. (ed.): Encyclopedia of world constitutions, Volume 2. New York, Facts on File, pp. 590-593.

Dübeck, I. (2007): Denmark. In: Robbers, G. (ed.): Encyclopedia of world constitutions, Volume 1. New York, Facts on File, pp. 250-254.

Duursma, J. (1994): Self-determination, statehood and international relations of micro-states. Leyden, University of Leyden.

Evans, C., Rogan, T. (2007): Australia. In: Robbers, G. (ed.): Encyclopedia of world constitutions, Volume 1. New York, Facts on File, pp. 47-56.

Farrell, D. M. (2001): Electoral systems. A comparative Introduction. New York, Palgrave.

Ferreres-Comella, V. (2000): A defense of constitutional rigidity. In: Comanducci, P., Goastini, R. (eds.): Analysis and Right. Turin, G. Giappichelli Publisher, pp. 45-68.

Floria, J. G. N. (2007): Argentina. In: Robbers, G. (ed.): Encyclopedia of world constitutions, Volume 1. New York, Facts on File, pp. 34-41.

Foley, E. A. (2007): Ghana. In: Robbers, G. (ed.): Encyclopedia of world constitutions, Volume 2. New York, Facts on File, pp. 346-350.

Frick-Tabarelli, M. (2013): Liechtenstein I. The parliament of the Principality of Liechtenstein. In: Baldwin, N. D. J (ed.): Legislatures of small states. London and New York, Routledge, pp. 56-64.

Ginsburg, T. (2011): Constitutional endurance. In: Ginsburg, T., Dixon, R. (eds.): Comparative Constitutional Law. Northampton MA, Edward Elgar, pp. 112-125.

Ginsburg, T., Melton, J. (2014): Does the Constitutional Amendment Rule Matter at All ? (Coase-Sander Institute for Law and Economics Working Paper No. 682). Retrieved from:

http://chicagounbound.uchicago.edu/law_and_economics

Hadenius, A. (1992): Democracy and development. Cambridge, Cambridge University Press.

Hagos, M. B. (2007): Eritrea. In: Robbers, G. (ed.): Encyclopedia of world constitutions, Volume 1. New York, Facts on File, pp. 291-294.

Hague, R., Harrop, M. (2004): Comparative government and politics, $6^{\text {th }}$ edition. New York, Palgrave Macmillan.

King, E. C. (2007): Federated States of Micronesia. In: Robbers, G. (ed.): Encyclopedia of world constitutions, Volume 2, New York, Facts on File, pp. 603-606.

Kwa, E. L. (2007): Papua New Guinea. In: Robbers, G. (ed.): Encyclopedia of world constitutions, Volume 3. New York, Facts on File, pp. 707-712.

Lay, J. P. (2007): France. In: Robbers, G. (ed.), Encyclopedia of world constitutions, Volume 1. New York, Facts on File, pp. 316-323.

Lijphart, A. (1984): Democracies. Patterns of majoritarian and consensus government in twenty-one countries. New Haven and London, Yale University Press.

Lijphart, A. (1999): Patterns of democracy: Government forms and performance in thirty-six countries. New Haven and London, Yale University Press.

Lipset, S. M., Lakin, J. M. (2004): The democratic century. Norman, University of Oklahoma Press.

Lorenz, A. (2005): How to measure constitutional rigidity. Journal of Theoretical Politics 17: 339-361.

Lundell, K. (2005): Contextual determinants of electoral systems choice. Åbo, Åbo Akademi University Press.

Lutz, D. S. (1994): Toward a theory of constitutional amendment. American Political Science Review 88: 355-370.

Mangu, A. M. B. (2007): Congo, Republic of the. In: Robbers, G. (ed.): Encyclopedia of world constitutions, Volume 1. New York, Facts on File, pp. 218-221.

Martins, L. (2007): Brazil. In: Robbers, G. (ed.): Encyclopedia of world constitutions, Volume 1. New York, Facts on File, pp. 125-131.

Obenaus, G. (2007): Liechtenstein. In: Robbers, G. (ed.): Encyclopedia of world constitutions, Volume 2. New York, Facts on File, pp. 539-542. 
Strong, C. F. (1958): Modern political constitutions. London, Sidgwick \& Jackson Ltd.

Suksi, M. (1993): Bringing in the people. Dordrecht, Martinus Nijhoff Publishers.

Taku, N. (2007): Cameroon. In: Robbers, G. (ed.): Encyclopedia of world constitutions, Volume 1. New York, Facts on File, pp. 157-161.

Thibaut, B. (1999): Seychelles. In: Nohlen, D., Krennerich, M., Thibaut, B. (eds.): Elections in Africa. A data handbook. Oxford, Oxford University Press, pp. 775-788.

Tsebelis, G. (2002): Veto players: How political institutions work. Princeton, Princeton University Press.

Windgätter, O. (2007): Mauritania. In: Robbers, G. (ed.): Encyclopedia of world constitutions, Volume 2. New York, Facts on File, pp. 585-589. 